\title{
The mineral chemistry of the megacryst suite from the Schuller and Premier kimberlites.
}

\author{
Deon De Bruin ${ }^{1,2}$ \\ ${ }^{1}$ Diamond Indicator Minerals Pty.Ltd., Perth, Australia deondebruin@iinet.net.au \\ ${ }^{2}$ CET, School of Earth and Environment, The University of Western Australia, Australia
}

\section{Introduction}

The Schuller and Premier kimberlites are situated approximately $30 \mathrm{~km}$ east-northeast of Pretoria, South Africa and occur in a cluster of eleven kimberlites of ca. 1180 Ma age (Allsopp et al., 1989).

Clinopyroxene, orthopyroxene and garnet megacrysts from the Schuller and Premier kimberlites were analysed for major elements by electron microprobe. The megacrysts phases from Schuller and Premier Kimberlites define unusually large compositional ranges and can be subdivided into a number of distinct chemical groups. The overall compositional range encompass and expand the range for both Cr-poor and Cr-rich clinopyroxene megacrysts from kimberlite localities world-wide (De Bruin, 1993).

The main groups were classified on the basis of clinopyroxene chemistry ( $\mathrm{Mg \#}, \mathrm{Ca} \#$ and $\mathrm{Cr}_{2} \mathrm{O}_{3}$ ) as: subcalcic low-Mg\# (group 1), sub-calcic intermediate to high $\mathrm{Mg \#} \mathrm{(group} \mathrm{2),} \mathrm{calcic} \mathrm{low-Mg \#} \mathrm{(group} 3$ ) and calcic high-Mg \# (group 4) varieties (De Bruin, 1993). The garnet and orthopyroxene megacrysts were also found to fall in distinct compositional groups but could not be linked to the clinopyroxene groups with confidence. In this study the additional analyses were obtained for orthopyroxene and garnet megacrysts from the Schuller and Premier Kimberlites.

The expanded data sets from Schuller were used to link the clinopyroxene and orthopyroxene groups on basis of similarities in the Ca\#, $\mathrm{Mg} \#$ and $\mathrm{Cr}_{2} \mathrm{O}_{3}$ distributions as shown in Fig. 1. The Mg\# vs. Ca\# plot for clinopyroxene and orthopyroxene megacrysts show a remarkably similary in distribution of the different compositional groups relative to the trend shown for Monastery megacrysts. A sample with co-existing group 3 clinopyroxene and orthopyroxene could be used to establish a direct link between these mineral groups. Three orthopyroxene megacrysts from Schuller, with the lowest Mg\# compositions were assigned to the group 1 population. Two co-existing group 4 orthopyroxenes and garnet were used to identify the corresponding group 4 garnet population. The garnet megacryst data set for Premier contained a low $\mathrm{Mg \#}$, low $\mathrm{Cr}_{2} \mathrm{O}_{3}$ content population that has the relative similar chemistry and characteristic to the Schuller group 1 clinopyroxene population. A single sample from Schuller fall within this garnet population Premier and thus establishes the presence of co-existing garnet with the group1 clinopyroxene megacrysts at Schuller.

At Schuller corresponding orthopyroxene and garnet populations exist that matches the four clinopyroxene megacrysts populations while at Premier three equivalent megacryst populations are present with corresponding garnet and clinopyroxene group 1 and 4 and corresponding garnet and orthopyroxene with group 2 clinopyroxene.

Single crystal clinopyroxene pressure temperature estimates show that the main groups have formed at different depth levels with groups 1 and 2 at deeper levels and higher temperatures and groups 3 and 4 at shallower depths and at lower temperatures (Fig. 2). 

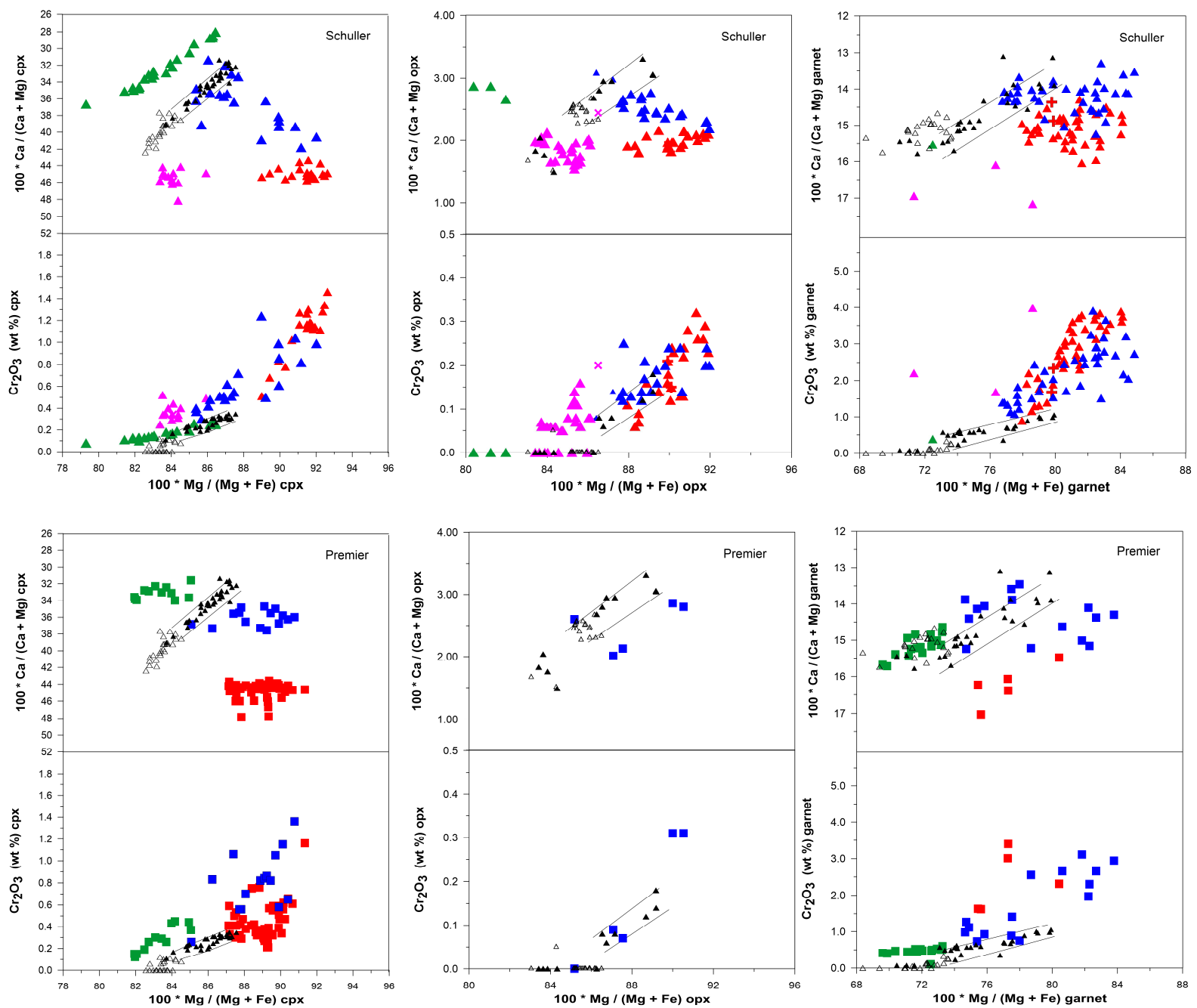

Figure 1. Ca\# and $\mathrm{Cr}_{2} \mathrm{O}_{3}$ vs. $\mathrm{Mg} \#$ for clinopyroxene, orthopyroxene and garnet megacrysts from Schuller and Premier. Symbols: Schuller (triangles) and Premier (squares). Megacrysts group 1 (green), group 2 (blue), group 3 (purple) and group 4 (red). The black symbols and boundary lines show the compositional spread of clinopyroxene megacrysts from Monastery (data from Jakob, 1977) where solid and open symbols represent the discrete and ilmenite associations, respectively. 

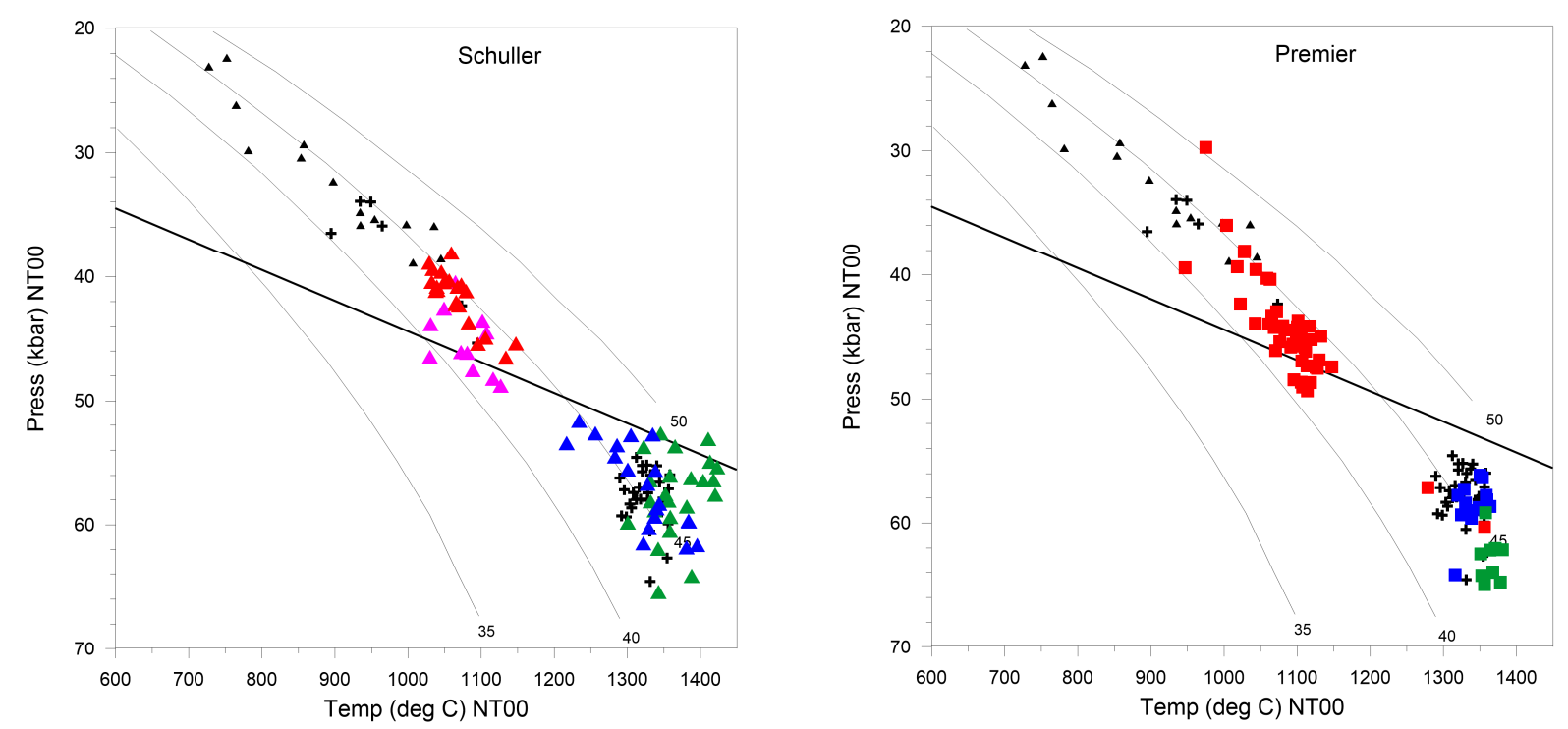

Figure 2. Pressure-temperature estimates for clinopyroxene megacrysts from the Schuller and Premier kimberlites using the single clinopyroxene thermobarometer of Nimis and Taylor (2000). Symbols as for Fig. 1 with black triangles and crosses representing values for lherzolite clinopyroxene for xenoliths from Schuller and Premier respectively. Reference conductive model geotherms with surface heatflows of $35,40,45$ and $50 \mathrm{~mW} / \mathrm{m} 2$ are those of Pollack and Chapman (1977). Graphite=diamond from Kennedy and Kennedy (1976).

\section{References}

Allsopp HL, Bristow, JW, Smith CB, Brown R, Gleadow AJW, Kramers JD, Garvie O (1989) A summary of radiometric dating methods applicable to kimberlites and related rocks. Kimberlites and Related Rocks, vol. 1, Their composition, occurrence, origin and emplacement. Spec. Publ.-Geol. Soc. Aust., vol. 14, pp. 343-357.

De Bruin D (1993) The megacryst suite from the Schuller kimberlite, South Africa. Geological Survey of South Africa Bulletin, 114, $17 \mathrm{pp}$

Jakob WRO (1977) Geochemical aspects of the megacryst suite from the Monastery kimberlite pipe, Unpublished M.Sc. thesis, University of Cape Town, South Africa, 81pp

Nimis P, and Taylor WR (2000) Single clinopyroxene thermobarometery for garnet peridotites. Part I. Calibration and testing of a Cr-in-Orthopyroxene barometer and an enstatite-in-Orthopyroxene thermometer. Contributions to Mineralogy and Petrology, 139, 541-554

Kennedy CS, Kennedy GC (1976) The equilibrium boundary between graphite and diamond. Journal of Geophysical Research 81, 2467-2470

Pollack HN, Chapman, DS (1977) On the regional variations of heat flow, geotherms and lithosphere thickness. Tectonophysics 38, 279-296. 